\title{
ДИЗАЙН СЕЛЕКТИВНЫХ ИНГИБИТОРОВ ФЕРМЕНТОВ НА ОСНОВЕ БИОИНФОРМАТИЧЕСКОГО АНАЛИЗА СУПЕРСЕМЕЙСТВ И КОМПЬЮТЕРНОГО МОДЕЛИРОВАНИЯ
}

\author{
В.К. Швядас ${ }^{1,2}$, Д.А. Суплатов ${ }^{3}$, Д.К. Нилов ${ }^{1,3}$, Е.М. Кирилинн, \\ ${ }^{1}$ Научно-исследовательский вычислительный центр, МГУ им. М.В. Ломоносова, Россия, \\ 119991, Москва, Ленинские горы, 1, стр. 4. \\ 2 Факультет биоинженерии и биоинформатики, МГУ им. М.В. Ломоносова, \\ Россия, 119991 Москва, Ленинские горы, 1, стр. 73. \\ ${ }^{3}$ Научно-исследовательский институт физико-химической биологии \\ им. А.Н. Белозерского, МГУ им. М.В. Ломоносова, \\ Россия, 119991, Москва, Ленинские горы, 1, стр. 40.
}

DOI: 10.19163/MedChemRussia2021-2021-170

E-mail:vytas@belozersky.msu.ru

До недавнего времени дизайн препаратов для подавления активности ферментов был основан на поиске конкурентных ингибиторов, предотвращающих связывание фермента с субстратами и кофакторами. В то же время наряду с активными центрами ферменты содержат множественные участки связывания, роль которых неизвестна [1]. Мы предлагаем использовать комплексный подход на основе биоинформатического анализа суперсемейств ферментов и молекулярного моделирования для идентификации новых регуляторных центров и выявления особенностей структурной организации активных центров, чтобы проводить поиск лигандов, способных оказывать селективное влияние на функциональные свойства выбранных мишеней. Разработана платформа веб-серверов (см. https://biokinet. belozersky.msu.ru/mustguseal, серверы Mustguseal [2], Zebra2 и 3D [3,4], pocketZebra [5], vsFilt [6], visualCMAT [7], представляющая возможность применения биоинформатических методов для изучения структурного и функционального разнообразия ферментов, поиска и классификации центров связывания лигандов. Разрабатываемый подход представляет общую методологию поиска модуляторов белков и ферментов - прототипов новых лекарственных препаратов. С его использованием обнаружены селективные ингибиторы ферментов Mycobacterium tuberculosis (транскетолазы, L,D-транспептидазы, глицеральдегид3-фосфатдегидрогеназы), способные подавлять рост патогена, селективные ингибиторы ферментов семейств поли(ADP-рибозо)-полимераз и металлопротеаз [8-10].

Исследования поддержаны Российским научным фондом (грант 21-71-30003).

\section{Литература}

1. Д. Суплатов, В. Швядас, Acta Naturae 2015, 7, 39-52.

2. D. Suplatov, K. Kopylov, N. Popova, V. Voevodin, V. Švedas, Bioinformatics 2018, 34, 1583-1585.

3. D. Suplatov, Y. Sharapova, E. Geraseva, V. Švedas, Nucl. Acids Res. 2020, 48, W65-W71.

4. D. Timonina, Y. Sharapova, V. Švedas, D. Suplatov, Comput. Struct. Biotechnol. J. 2021, 19 , 1302-1311.

5. D. Suplatov, E. Kirilin, M. Arbatsky, V. Takhaveev, V. Švedas, Nucl. Acids Res. 2014, 42, W344-W349.

6. I. Gushchina, A. Polenova, D. Suplatov, V. Švedas, D. Nilov, J. Chem. Inform. Model. 2020, 60, 3692-3696.

7. D. Suplatov, Y. Sharapova, D. Timonina et al., J. Bioinform. Comput. Biol. 2018, 16, 1840005.

8. Д.К.Нилов, И.В. Гущина, Т.А. Щербакова, С.М. Балдин, В.К. Швядас, Патент RU 2703465 , 2019.

9. Д.А. Суплатов, Е.В. Шмальгаузен, В.И. Муронец, В.К. Швядас, Патент RU 2661 151, 2018.

10. Manasaryan, D. Suplatov, S. Pushkarev, V. Drobot et al., Cancers, 2021, 13, 1201-1201.

$$
-170-
$$

